\title{
EGY ELMÉLET MINDENEK FELETT: VÁLTOZÁS ÉS ÁLLANDÓSULÁS A DEMOGRÁFIAI ÁTMENET TUDOMÁNYOS KÖZGONDOLKO- DÁSÁBAN*
}

\section{Illés Tamás}

\section{ÖSSZEFOGLALÓ}

A demográfiai átmenet elméletét a társadalomtudományok egyik legismertebb modelljeként tartják számon. A tanulmány a nyugati diskurzusok kritikai elemzésével ismerteti az átmenet-elmélet keletkezésének körülményeit, valamint felvázolja a felívelésének megágyazó szellemtörténeti, kulturális és politikai kontextust. Mindezzel együtt sor kerül a modell teleologikus, valamint a modernizációs paradigmára építő jegyeinek dekonstrukciójára. Ugyanakkor a tanulmány részletes irodalmi áttekintéssel a demográfiai hagyomány átmenetiségre vonatkozó gondolkodási sémáit is körvonalazza. Ennek során bizonyitást nyer, hogy az európai termékenységi projekt (EFP) során episztemológiai alapként alkalmazott természetes termékenység gondolatköre hogyan betonozott be egy dichotomikus demográfiai korszakolást, és a demográfiai időfolyam ilyetén szakaszolása hogyan vezetett a termékenység és halandóság kauzális viszonyának felállításához. A tanulmány végkövetkeztetése szerint az átmenet-elmélet a homeosztázis keretezésében csak egy mély intellektuális diskurzus precízebb és szabatos formába öntését jelentette, amely már létrejöttének pillanatában minden téren a nyugati népességpolitikai igényekhez igazodott és a későbbi évtizedekben is ezek mentén konzerválódott.

\footnotetext{
*Az Innovációs és Technológiai Minisztérium ÚNKP-20-4 kódszámú Új Nemzeti Kiválóság Programjának a Nemzeti
} Kutatási, Fejlesztési és Innovációs Alapból finanszírozott szakmai támogatásával készült. 
Tárgyszavak: demográfiai átmenet elmélete, népességpolitika, EFP, természetes termékenység, homeosztázis

Illés Tamás, Eötvös Loránd Tudományegyetem, Társadalom- és Gazdaságföldrajzi Tanszék

E-mail: tamas.illes92@gmail.com

\section{BEVEZETÉS}

Minek tulajdonithatóan azonositjuk a termékenységi vagy halandósági szintek tendenciózus csökkenésének megjelenését rögtön a demográfiai átmenet kibontakozásának kezdetével, legyen szó a modern kor bármely időszakáról vagy a világ bármely földrajzi pontjáról? Miként lehetséges, hogy miközben a demográfusok az episztemológiai kérdésektől és elméleti vitáktól „tisztes távolságot” tartottak (Vance, 1952; Greenhalgh, 1996; Petit and Charbit, 2012), addig a demográfia mégis képes volt kitermelni a társadalomtudományok egyik legismertebb és legnagyobb hatású generalizálását? A demográfiai átmenet elméletével, illetve az attól elválaszthatatlan, népesedési szakaszokat bemutató ábrával bizonyára már mindenki találkozott, hiszen mind a mai napig megkerülhetetlen részét képezik minden népességföldrajzi-demográfiai tankönyvnek. Az átmenet-elmélet sarokpontjai máig meghatározzák a demográfiai kutatások kérdésfeltevéseit vagy éppen az eredmények interpretációs lehetőségeit, az elméletben meghúzódó társadalomfilozófiai alapállások pedig továbbra is szervezik a demográfiai változáshoz füződő kutatói attitüdöket.

Ennek ellenére a demográfiai átmenet kapcsán a hazai kutatók többnyire csak a szakaszok általános jellemzésére szorítkoztak (Katus, 1980; Hablicsek, 1995), vagy pedig empirikus oldalról kifogásolták az elmélet szerint predesztinált népesedési pályákat (Valkovics, 1982; Dányi, 1977, 2000). Az átmenetelmélet és a hozzá tartozó ábraváltozatok normatív szerepeltetésének és a kontextualizálás hiányának az lett az eredménye, hogy az elmélet egy olyan megkerülhetetlen alapigazságként rögzült a demográfiai hagyományban, mely nem szorul különösebb magyarázatra. Mindez pedig az egyetemi kurzusokon túlmenően a közoktatásban is érezteti hatását (Czirfusz, 2020). A magyar szakirodalom tehát továbbra is adós az elmélet kialakulási körülményeinek, valamint évtizedekre visszanyúló globális konzerválódásának be- 
mutatásával, továbbá az elméletben bekövetkezett változások feltárásával.' E szakirodalmi hiátus (remélt) betöltésével a tanulmány célja egyszersmind a demográfiai átmenethez füződő tudományos közgondolkodás kibontása.

Az elmélet értékelése két síkon halad. Elsőként a nyugati demográfiai diskurzusok kritikai elemzésével bemutatom az elmélet kialakulását és a szélesebb szellemtörténeti, tudomány- és világpolitikai kontextus felvázolásával hosszú távú sikerének okait. Folytatásként a demográfiai tudástermelés mozgásterének változásával szemléltetem az elmélet presztízsveszteségéhez vezető utat különös tekintettel az ún. európai termékenységi projekt (EFP) jelentőségére. A tanulmány másik síkja módszertani és empirikus példákon keresztül az átmenetiséghez füződő kutatói viszonyulás változásának érzékeltetésére vállalkozik. Ennek keretében sor kerül az átmenet-elmélethez szorosan kötődő demográfiai korszakolás kérdéskörének tárgyalására, többek között rámutatva arra, hogyan vezetett mindez a ma is használatban levő, az átmenetet szemléltetni hivatott ábrák sokszínüségéhez. Végezetül a homeosztázis fogalmának ismertetésével és kritikájával rávilágítok az átmenet-elmélet, valamint a malthusianizmust megalapozó gondolkodási sémák közötti folytonosságra.

A vizsgálati célokhoz illeszkedően az átmenet-elmélet két konceptuális öszszetevője közül a termékenység kap majd nagyobb hangsúlyt, mivel a termékenységi átmenethez kapcsolódó diskurzusok - mint látni fogjuk - alapjaiban befolyásolták a demográfiai átmenethez füződő kutatói viszonyulásokat. Így eltekintek a magyar szakirodalomban már többször is tárgyalt epidemiológiai átmenet bővebb kifejtésétől (Id. Kovács, 2011; Bálint 2016), ugyanakkor tartalmi korlátok miatt a termékenység-elméleteknek (Id. Andorka, 1987) is csak a téma szempontjából releváns pontjait ismertetem.

\section{AZ ELMÉLET MEGFOGALMAZÁSA ÉS MEGSZILÁRDULÁ- SÁNAK KONTEXTUSA}

A demográfiai átmenet modelljének forrásmegjelölés nélküli szerepeltetése azt a képzetet erősíti, hogy a globális népességváltozás organikusan kifejlődött ábrázolási módjával van dolgunk. Mint minden tudományos koncepció, természetesen az átmenet-elmélet sem egy értéksemleges vá-

${ }^{1}$ Témánk szempontjából a szakirodalmi palettán üde színfoltot jelent Melegh Attila munkássága, aki többször is foglalkozott az átmenet-elmélet történetével (Melegh 2000, 2006, 2014) - jóllehet elsődlegesen a biopolitikai vonatkozásokra koncentrálva. 
kuumban jött létre, hanem magán viselte az adott kor és földrajzi tér viszonyait. A közmegegyezés Frank W. Notesteint tartja az elmélet szülőatyjának, azonban az előzmények között szükséges kitérnünk Warren S. Thompson (1929) tanulmányára, melyben már megjelentek az elmélet első körvonalai. Thompson három csoportra osztotta a világ országait (A, B és C csoport) termékenységi és halandósági szintjeik kombinációja alapján. Az első csoportba kerültek a belátható időn belül népességcsökkenéssel szembesülni kényszerülő nyugat-európai országok, valamint az európai emigrációval érintett földrészek. A Kelet- és Dél-Európa országaiból verbuválódó B csoportot az enyhén csökkenő termékenységi és a meredeken zuhanó mortalitási szintek hasonlósága tartotta össze, így ez a kör még az erőteljes népességnövekedési fázisban „vesztegelt”. 2 Thompson a C csoportot Oroszország, India és Japán hármasából állította öszsze, illetve ide tartozott még az „adatokat felmutatni se tudó világ többi része”. Ugyan Thompson soraiból a demográfiai események teleologikus lefolyásának feltételezése vehető ki, a szerző csak érintőlegesen bocsátkozott jövőpuhatoló forgatókönyvek felvázolásába, illetve arról is keveset árult el, hogy a csoportképző sajátosságok milyen történelmi kölcsönhatások révén alakultak ki. Így Thompson kategorizálása inkább tekinthető egy térségek mentén differenciált pillanatfelvételnek, mintsem egy szisztematizálásra való törekvésnek.

Thompsonnal egy időben több európai kutatót is foglalkoztatott a demográfiai jelenségek makroszintű vizsgálata (pl. L. Brentano, A. M. Carr-Saunders, L. Rabinowicz, Adolphe Landry), jóllehet egyikük sem jutott el globális léptékű keretrendszerek felállításáig. Ilyen téren valószínüsíthetően Landry jutott a legmesszebb, ugyanakkor Thompsonhoz képest nála a térbeli helyett inkább az időbeli szempontok kaptak hangsúlyosabb szerepet a demográfiai rezsimek szakaszolásához (Landry, 1934). Az első, általa primitívnek nevezett rezsimben (régime primitif) a népességméretet elsődlegesen a gazdasági tényezők korlátozták a magas halandóságon keresztül. A modern vagy jelenkorinak nevezett rezsimben (régime contemporain) a demográfiai viselkedést elsősorban már a magas életszínvonalat előtérbe helyező egyéni aspirációk határozták meg. Landry szerint a két rezsim olyannyira különbözött egymástól, hogy a változáshoz - munkájának címét is adó (La Révolution Démographique) - demográfiai forradalomra volt szükség. A forradalom kibontakozásának időszakát (phase intermédiaire), vagyis a primitívből a modern rezsimbe történő elmozdulást Landry elsőként címkézte demográfiai átmenetnek a szakirodalomban.

Érdekességképp, Thompson ebben az országcsoportban Spanyolország és Olaszország nevesitésén kivül a maradék halmazt csak nagyvonalúan „szláv országoknak” címkézte. 
A demográfiai átmenet e két prototípusa csupán a szorosan vett szakmai berkekben váltott ki visszhangot. Jellemző módon Thompson saját okfejtését olyannyira nem tekintette hivatkozási alapnak, hogy többet ő maga sem hozakodott elő ezzel (Kirk, 1996). Másfelől Landryt parlamenti képviselői minőségéből adódóan jobban érdekelte a demográfiai forradalomból bekövetkező „társadalmi dekadencia” és depopuláció rémképe, semmint az általa felvázolt történelmi átmenet további tudományos vonatkozásai (Landry, 1987). Ilyen előzmények után meglepőnek tünhet, hogy alig két évtizeddel később, a minimális ráncfelvarráson átesett átmenet-elmélet Frank W. Notestein és Kingsley Davis munkái révén szinte berobbant mind a kutatói, mind a döntéshozói köztudatba. A demográfia korabeli viszonyait jól ismerő S. Szreter $(1993,661$. o.) így vallott az elmélet áttöréséről: „Úgy tűnik, hogy akkor még halva született ahhoz, hogy 16 évvel később kedvenc gyermekként szülessen újra” ${ }^{3}$

Szinte biztosra vehető, hogy a princetoni intézet demográfusai inspirációként nyúltak a demográfiai fejlődést taglaló korábbi munkákhoz - ezt jelzi, hogy ők maguk is hármas osztályozást alkalmaztak -, ugyanakkor az átmenet szikráját az addigi domináns szellemi (ideational) tényezők helyett a modernizációban és annak gazdasági aspektusaiban vélték felfedezni (van de Kaa, 1996). Érvelésükben az ipari forradalom a javuló egészségügyi-higiéniai feltételek és a biztosabb élelemellátás folyamatain keresztül növekvő életszínvonalat és csökkenő halandósági szinteket eredményezett, „miközben a termékenység kevésbé volt reszponzív a modernizáció folyamataira” (Notestein, 1945, 39. o.). Vagyis a társadalmak évszázadokon keresztül a magas termékenység és magas halálozás „népesedési csapdájában tengődtek”, míg a növekvő életszínvonal ki nem nyitotta a demográfiai ollót. Davis (1945) meglátása szerint épp a korai demográfiai átmenet biztosította Európa számára a világdominanciát, mivel az európaiak a javuló életkilátásaik folytán sokkal gyorsabban „multiplikálódtak" a világ többi részéhez képest. Notestein (1945) az átmenet sarokpontjait rögzítő tanulmányában pedig rámutatott arra, hogy mindehhez Európában azért volt lehetőség, mert a halandóság csökkenésének nem voltak társadalmi gátjai, viszont a magas termékenységi szintek és az azokat szavatoló vallási doktrínák, házasodási szokások, családi közösségek és egyéb intézmények csak lassú változásra voltak képesek. Ugyanakkor mindkét elméletalkotó szerint a modernizáció által támasztott új feltételek e társadalmi alrendszerek szükségszerű változását is magukkal vonják, így - ugyan némi időbeli csúszással -

${ }^{3} 1945$-ben Notestein a princetoni székhelyủ Népességtudományi Hivatal (Office of Population Research) alapító igazgatója volt, Davis pedig az intézet szenior munkatársa. 
a termékenység csökkenése is borítékolható. Ahogy Davis $(1945,5$. o.) fogalmazott: „a kompetitív, individualista, felemelkedő urbánus társadalom a nagy családokat hátránnyá, mintsem áldássá tette".

A felvázolt modell tehát lényegében egy magas és egy alacsony egyensúlyi állapoton, valamint a köztük lévő átmeneten alapult. Az átmenet lineáris lefolyása ennek megfelelően egyszeri és elkerülhetetlen (Johnson-Hanks, 2008), annak elindulása után pedig megfordíthatatlan (Burger and DeLong, 2016). Az egyetlen eldöntendő kérdést már csak az jelentette, hogy az adott országok hol tartanak ebben a folyamatban: „A demográfiai ügyeket illetően a világ különböző országai úgy értelmezhetők, mint amik a fejlődés egyetlen kontinuumán vannak" (Kirk, 1944, 29. o.). Az országok beskatulyázásának paraméterei viszont szükségszerüen a kulturális esszencializmus jól bejáratott normái szerint alakultak. Így a felelősségteljes „európai szellemiségü” országok váltak a demográfiai fejlődés vonatkoztatási pontjává, míg velük szemben állt a civilizációs vívmányok nélküli, átmenetben lemaradtak sokasága (Blaut, 1993).

Notestein ebben a szellemiségben az első demográfiai típusba sorolta a fejlett világ azon térségeit, ahol a termékenység a reprodukciós szint közelébe vagy az alá csökkent. Érdemes felidézni, hogy a publikáció közlésének időpontjában, közvetlenül a második világháborút követő „,baby boom” tapasztalata előtt, a nyugati világban inkább a népességfogyástól való félelmek voltak erősebbek (ld. Teitelbaum and Winter, 1985). Ezért nem is meglepő, hogy ennek elkerülését Notestein (1945, 42. o.) csak „lényegében totalitárius-fajta” kormányzati politikákkal vagy bevándorlással tartotta elképzelhetőnek. A második demográfiai típus a Thompson által felvázolt jegyekkel szinte teljes átfedést mutatott, annyi eltéréssel, hogy itt Kelet-Európa már e demográfiai fázis végéhez közelített. Szintén az átmenet-elmélet logikájába kódolt linearitást érzékeltette, hogy Notestein - Thompsonhoz képest - már csak a világ népességének „,premodern” felét sorolta a harmadik, demográfiai átmenetük kezdetén lévő térségek csoportjába. Ez az országtipizálás tökéletesen megfelelt az elméleti osztályképzés legfontosabb ismérveinek, melynek logikája Bourdieu (2002 [1994], 21-24. o.) útmutatása alapján nem elégedett meg az osztályokba sorolt társadalmi térelemek összességének leírásával, hanem a többi tulajdonság előrejelzését is magában foglalta.

A népesedési adatokkal gazdagon megfüszerezett sorokból éppen a minél pontosabb népességelőrejelzés kívánalma bontakozott ki, amelyhez csupán az átláthatóság miatt kerültek az országok három csoportba - érdekességképp, 2020-ra 3,3 milliárd fős világnépességet prognosztizálva. Ezt a megállapítást látszik alátámasztani, hogy elképzelését Notestein elsőként egy, a háború utáni 
élelmiszerellátás problémáit feszegető, szélesebb szakmai közönséget felvonultató konferencián mutatta be. Mindez nem véletlen, hiszen közvetlenül a háború befejezésével a tervezőknek egy kompakt, könnyen használható előrejelzésre volt szükségük arról, hogy hol mekkora népességváltozás várható. Az új nemzetközi kontextus fényében a siker garantálható volt, hiszen az elmélet egyszerre mondott el - van de Kaa (1996) megfogalmazásával élve - egy „jó sztorit”, a sok egyedi esetet, illetve a közöttük fennálló bonyolult hatásmechanizmusokat pedig egy jól követhető logikai váz mentén sikerült a globális porondra kivetítenie - egyszerre teljesítve egy elmélet és metanarratíva kritériumait (Graham, 2000).

Mint látható, az átmenet-elmélet csak részleteiben és kidolgozottságában különbözött elődeitől, így nem téved sokat az a francia szerző, aki vélhetően nemzeti önérzetből a demográfiai átmenet elméletét egyenesen Landry szellemi termékének tekinti (Girard, 1982). Ugyanez elmondható a másik kútfőnek tekinthető Thompsonról, aki hiába volt Notesteinhoz hasonlóan korának vezető amerikai demográfusa, 1929-es publikációja idején még nem voltak adottak a társadalmi tervezés (social engineering) és a keynesiánus gazdaságpolitika olyan szintű keretei, amelyek reflektorfénybe helyezhették volna a globális demográfiai folyamatok kérdéskörét (Szreter, 1993). ${ }^{4}$ A hidegháború eszkalációjával nemcsak az amerikai kormányzati politika, hanem a magánszféra (Rockefeller Foundation, Ford Foundation, Milbank Memorial Fund, Carnegie Corporation) tekintete is a nemzetközi ügyek felé irányult, ezáltal az általuk bőkezűen támogatott demográfiai kutatások disszeminációja is szélesebb publikumot ért el. Ezzel a zászlóshajó szerepében tetszelgő demográfiai átmenet világkörüli útja után gyorsan lehorgonyzott narratíva lett (ld. Mackenroth, 1953). Ezzel együtt a demográfia tudományának sorsa az átmenet-elmélet nimbuszával végérvényesen összekapcsolódott. Feltehetően Vance (1952) a kor demográfusainak konszenzusát juttatta kifejezésre, amikor a demográfiai átmenetet reménykedve egy olyan szisztematikus keretrendszerhez hasonlította, amivel a tudományág végre felzárkózhat a kumulatív, hipotézistesztelő természettudományokhoz.

\footnotetext{
${ }^{4}$ Megjegyzendő, hogy Thompson a két világháború között a világ veszélyzónáiról irt demográfiai munkájában az európai gyarmattartó országokat arra intette, hogy a lakatlan csendes-óceániai területeiket békés úton engedjék át a „„úlnépesedô” Japánnak, hogy ezzel elkerüljék egy lehetséges háború kibontakozását. Ugyan Thompson népsürüségi különbségekböl levezetett neomalthusiánus diagnózisa a korabeli akadémikusok többségi véleményét tükrözte (Id. Bashford, 2014, 55-106. 0.), a megoldási javaslat - kiváltképp a döntéshozói szférában - már kevesek tetszését nyerte el (Hodgson and Watkins, 1997, 477. 0.).
} 


\section{A MORÁLIS IRÁNYTÜKÉNT ALKALMAZOTT ÁTMENET- ELMÉLET}

Az elmélet rendkívül kézenfekvő eszközt nyújtott a tervezőasztalok mellett tüsténkedőknek, hiszen egyszerre tartalmazott egy „fejlett nyugathoz” viszonyított ország-taxonómiát és kompakt prognózist a várható globális népességfejlődési folyamatokról (Szreter, 1993). A modell szellemiségén már érzékelhető a következő évtizedeket meghatározó tudományos pozitivizmus előszele, amely a társadalomtudományok küldetését a politikai döntéshozás adat-alapú támogatásában jelölte ki (pl. szociológia kapcsán Id. Rawls, 2018; a földrajz esetében pedig Barnes, 2004). Notestein az elmélet kifejtése során ennek tudatában érvelt a beavatkozások szükségessége mellett: „A Nyugat modern nemzetei a világ nem-iparosított népeire rárakták kultúrájuk azon részét, amely eléggé csökkenti a halandóságot a növekedéshez, ugyanakkor visszatartva vagy elmulasztva azon társadalmi változások elősegítését, amelyekből végső soron kialakult a termékenységcsökkenés a Nyugaton" (Notestein, 1945, 51-52. o.). Az intervenciós politika hasonló megágyazását sürgették Davis (1945, 4. o.) észrevételei is: „A kiterjedt, primitiv és archaikus társadalmakban, ahova a modern civilizáció csak kevéssé hatolt be, a születési ráták általában magasak". Így lett a demográfiai átmenet lezajlásának egyetlen lehetséges útja a modern gazdasági feltételekhez történő sikeres kulturális adaptálódás. Mivel a célba vett „túlnépesedő” országokban előbb e gazdasági feltételek megteremtésére volt szükség, az elmélet alkalmazása szükségszerűen az ötvenes évek fő társadalomtudományi csapásirányának számító (Knöbl, 2003) modernizációs elmélethez igazodott.

Az elodázhatatlannak tűnő drámai beavatkozásokhoz az amerikai külpolitika rövidesen a szükséges társadalmi felhatalmazást is megkapta a túlnépesedéstől való félelem hozományaként. ${ }^{5}$ Érdekes módon a demográfiai átmenet elméletének kidolgozói ebben is közvetett szerepet játszottak. Davis sokat hivatkozott tanulmányában a Föld népességváltozását egy gyújtózsinórhoz hasonlította, amely „lassan és nehézkesen ég, míg végül eléri a töltetet, és felrobban” (Davis 1945, 1. o.). Feltehetően e sorok írásakor maga a szerző sem gondolta, hogy a problémakör érzékeltetéséhez használt metaforája rövidesen a népesedés-

\footnotetext{
${ }^{5}$ Természetesen nem mindenki rajongott a globális léptékủ népességszabályozás ötletéért. Az egyik leghangosabb kritikusként a francia demográfus Alfred Sauvy például a Föld túlnépesedését egy érzelmileg túlfütött, hamis problémának titulálta, és a határokon átnyúló intervencionizmussal szemben a nemzeti szuverenitás sérthetetlensége mellett foglalt állást (Keyfitz, 1990). A szocialista és katolikus országok - látszólag paradoxnak tűnő - koalíciója pedig egészen a hetvenes évekig következetesen blokkolt bármilyen népességszabályozási javaslatot az ENSZ-ben.
} 
politikai diskurzus megkerülhetetlen képzettársítása lesz. A Hugh Moore Fund gondozásában 1954-ben megjelent röpirat Davis „vékony és hosszú gyújtózsinórját” egy huszárvágással lerövidítette, a szerkezetet pedig a nukleáris korszakhoz illően felnagyította. Ezzel megszületett és gyors hírnévre tett szert a népességbomba (population bomb) ideája, ami „egy olyan repesztő és veszélyes robbanással fenyeget, mint az atom robbanása, és ugyanolyan befolyással lesz a haladás vagy katasztrófa, háború vagy béke kilátásaira” (idézi Mass, 1974, 659. o.). ${ }^{6}$ Félő volt, hogy az ehhez hasonló nyers megnyilvánulások nemcsak kontraproduktiv hatással lesznek a népesedési kérdések higgadt megvitatására, hanem a demográfia tudományos legitimációját is megkérdőjelezik. A vezető demográfusok a röpirat kapcsán hangot is adtak aggodalmuknak, a Population Council elnöki tisztségét betöltő Frederick Osborn pedig egyenesen a röpirat betiltását követelte - jóllehet egy későbbi interjúban beismerte, hogy „,a bomba” nagyban hozzájárult az alapítványok és mecénások pénztárcájának a demográfiai kutatások irányába történő kinyitásához (Lader, 1971).

Egy másik társadalmi és részben tudományos felhajtó erőt az eugenikus mozgalom biztosította. Szószólói a második világháborút megelőzően még jobbára a bevándorlók és alsóbb osztályok jelentette társadalmi degenerációtól tartottak, az új diszkurzív térben azonban félelmüket már nem a belföldi népesség minősége, hanem a harmadik világbeli népesség mennyisége táplálta (Connelly, 2003). Az új eugenikai hitvallást kitűnően summázta Julian Huxley, az UNESCO első főigazgatója és az Eugenikai Társaság későbbi elnöke, amikor az ötven- és hatvanas évek világát úgy jellemezte, melyben „a mennyiség a minőséget veszélyezteti” (idézi Bashford ,2014, 332. o.). Hogy kinek jutott a mennyiségi és kinek a minőségi szerepkör, azt jól érzékeltette Notestein egy 1959-ben irt feljegyzése: „Mindannyian meggyőződtünk arról, hogy ami a nyugati világot illeti, a fontos kérdések valószínüleg inkább kvalitatívak, mint kvantitatívak" (idézi Connelly, 2008, 160. o.).

A nyugati életszínvonalat a harmadik világ túlnépesedésétől féltő társadalmi hisztéria tökéletes fokmérője volt a 20 kiadást és 2 milliós példányszámot megélt, „A népességbomba” című kötet, amely már bevezetőjének legelső mondatában százmilliók elkerülhetetlen éhhalálát vetítette előre (Ehrlich, 1968). Ilyen előzmények után aligha meglepő, hogy az alsóbb osztályok foucault-i értelemben vett

\footnotetext{
${ }^{6}$ Stycos (1977) érzékletesen ecseteli az üzleti tevékenységét maga mögött hagyó és figyelmét a túlnépesedés irányába fordító Hugh Moore elhivatottságát. Moore röpiratával tudatosan nem az akadémiai köröket vette célba, hanem a legbefolyásosabb embereket gyűjtő Who's Who katalógusán végighaladva mindenkinek küldött egy példányt. Az 1960-as évek közepére a tizenharmadik kiadásánál és 1,5 millió példánynál járó röpirat így túlzás nélkül a teljes amerikai felsőosztályhoz eljutott.
} 
biopolitikai kontrolljának kivánalma a demográfiai átmenet elméletének farvizén milyen könnyen kivetült, egyben rásimult a harmadik világ népeinek halmazára (Melegh, 2006). Az elmélet morális iránymutatásának értelmében tehát a gazdag Nyugatnak kötelessége segíteni elsősorban a távol-keleti népek fejlődését, hogy megmentse a Földet a túlnépesedéstől. Ugyan Notestein ágendája ehhez egy ambiciózus, hosszú távú stratégiát igényelt, a világpolitikára nehezedő hidegháborús kontextus rövidesen az elmélet korrekcióját kényszerítette ki. Egy 1953-ban tartott agrárgazdaságtani konferencián Notestein már az Európa által bejárt demográfiai pálya transzferálhatóságát illetően is elbizonytalanodásának adott hangot. Aggodalma arra irányult, hogy a fejlődő országokban a gazdasági növekedésre megkésve - vagy akár másképp - fog reagálni a termékenység: „Egyetlen kormány vagy nemzetközi szervezet sem engedheti meg magának a hoszszú távú szemléletet azonnali vészhelyzetek nyomása alatt" (Notestein 1953, 26. o.). Úgy tűnik, a demográfusok kezdetben hiába tartották a gazdasági növekedést az egyetlen biztos fogamzásgátlónak, a népességbomba ketyegése közben nem volt idő a modernizáció lassú hatásait kivárni (Friedlander et al., 1999). A vészjósló forgatókönyvek a döntéshozók számára egyértelműsítették, hogy az exponenciális népességnövekedéssel szűkülő erőforrások társadalmi konfliktusokhoz vezetnek, ami az egyenlőséget hirdető kommunista mozgalmak hatalomátvételének ágyazhat meg (Greenhalgh, 1996). ${ }^{8}$ Amikor az USA befolyásos üzletemberei levélben fordultak a Population Council-t alapító III. John D. Rockefellerhez, nem palástolták a népességpolitika iránti érdeklődésük mozgatórugóit: „Elsősorban a születésszabályozásnak nem a szociológiai vagy humanitárius szempontjai érdekelnek minket. Minket az érdekel, hogyan használják ki a kommunisták az éhes embereket a föld meghódítására” (idézi Critchlow, 1999, 32. o.). ${ }^{9}$ Mindezzel együtt a negyvenes évek végétől az angolszász népesedési diskurzusokon a kommunizmus előretörésétől való félelem jegyében a malthusiánus vonások is egyre nagyobb nyomot hagytak (Frey, 2011).

\footnotetext{
${ }^{7}$ Notestein megfigyelése alapján - számos ellenpélda mellett - mindaddig csak Japán pályája alakult a várakozásoknak megfelelően.

${ }^{8}$ Notestein (1953) számításai szerint a legsürübben lakott, és ezáltal „legveszélyesebb” távol-keleti országokban a gazdasági fejődés által kiváltott demográfiai olló évi 2-3\%-os népességnövekedést eredményezne legalább két generáción keresztül, melynek felszívásához a mezőgazdasági termelékenység legalább évi 2\%-kal, a szekunder és tercier szektor pedig évi 5\%-kal kellene, hogy növekedjen. A számítások arról győzték meg Notesteint, hogy pusztán gazdasági beavatkozással valószínüleg csak még nagyobb bajt okoznának.

${ }^{9}$ Míg a princetoni demográfusok többsége (mint pl. I. Taeuber, D. Kirk, F. W. Notestein) meghagyta volna a demográfiai átmenetet egy humanitárius célokat szolgáló elméletnek, addig mást gondolt erről Davis, aki a világ el nem kötelezett részéről úgy tartotta, hogy az egy „elnyerésre váró jutalom a kommunista és szabad világok harcában” (idézi Hodgson 1988, 547. 0.).
} 
A vezető demográfusok lépéskényszerbe kerültek. A befolyásos Princetoni Iskola munkatársai körében továbbra is fennmaradt az a vélekedés, hogy a kultúrák közötti demográfiai különbségeket mélyen beágyazott szociokulturális folyamatok termelik ki, de a friss lendülethez jutó konszenzus a nemzeti lépték alatt már nem zárta ki bizonyos beavatkozások megtérülési lehetőségét (Szreter, 1993). Ahogy arra Notestein (1953, 27. o.) is utalt: „Tudjuk, hogy nagy az ellenállás, de megfelelő körülmények között, valami elérhető”. Ennek eredményeként a modernizáció indikátorai lettek a függő változók, a termékenységre pedig kezdtek úgy tekinteni, mint ami a demográfiai változás többi folyamatától függetlenül oszcillál a történelem folyamán, így különböző intézkedésekkel befolyásolható (Rao, 2004). Az átmenet-elmélet rugalmas keretei nem gördítettek akadályt e konceptuális váltás elé.

A liberális eszmék terjesztésében érdekelt amerikai külpolitika vonakodott a kommunizmusra jellemző nagy társadalom-átalakító programokba fektetni (holott az eredeti elmélet értelmében erre lett volna szükség), így egyetlen beavatkozási lehetőségként a gyors hasznot ígérő családtervezési programok maradtak (Szreter, 1993). Mivel a demográfiai átmenet elméletét a társadalmi tervezés emelte fel, így ennek változásával az elméletnek is változnia kellett. Nem véletlen, hogy néhány évvel később Notesteint és Davist is a gyors eredményeket ígérő családtervezési programok szószólói mellett találjuk, és - szemben korábbi meggyőződésükkel - a kínálati oldalon történő beavatkozást szorgalmaztak. Friss meggyőződésüket elsősorban az a félelem vezérelte, hogy a gazdasági beavatkozások „rosszabbak, mint hasznosak” (Notestein, 1953, 24.), mert ezek a halandóság mérséklésével végeredményben csak még nagyobb népességnövekedéshez vezetnek. Davis pedig arra figyelmeztetett, hogy a termékenység csökkentésének elmulasztása a modernizációs sikereket is esetlegessé és múlandóvá teheti (Davis, 1956). Tehát amíg az elmélet eredeti interpretációjának értelmében a modernizáció elmaradása a túlnépesedés veszélyével fenyegetett, az ötvenes évekre a hidegháborús nyomás megfordította ezt a kapcsolatot, melynek fényében már a túlnépesedés veszélyeztette a kommunista agitáció legjobb ellenszerének tartott gazdasági fejlődést. Ennek eredményeként vált a családtervezés az USA külföldi modernizációs csomagjának megkerülhetetlen részévé, egyben a folyósítások feltételévé egészen a nyolcvanas évek végéig (Frey, 2011). Az amerikai segélyezés müködésén egyszerre volt kivehető a felkorbácsolt közhangulat által elnyomott szofisztikált álláspontok hiánya, illetve az átmenet-elmélet univerzalista iránymutatása, mely szerint ugyanarra a problémára ugyanaz a megoldás alkalmazandó (Sharpless, 1995). 
A demográfiai átmenet keresletiből kínálati elméletté történő metamorfózisához túlzott paradigmaváltásra nem volt szükség, hiszen az átmenet-elmélet annak a mélyen gyökerező intellektuális diskurzusnak a kicsúcsosodását jelentette, ami Malthustól az eugenikusokon át az iskolateremtő közgazdászokig (pl. A. Marshall, J. M. Keynes) születésszabályozást sürgetett (Caldwell, 1997) - elsősorban a világ 5/6-át kitevő „nem-felvilágosult népesség” körében (Ross, 1928). Másrészt a népességpolitika eszköztárában ténylegesen csak a demográfiai átmenet termékenységre és halandóságra fókuszáló konceptuális tengelyei maradtak, miután a Rockefeller által összehívott 1952-es williamsburgi tanácskozáson a „demográfia nagy öregjeként” már Warren $\mathrm{S}$. Thompson is amellett érvelt, hogy az általa addig következetesen támogatott áttelepítések és a spontán migráció nem fogják tudni elvégezni a túlnépesedés veszélyének kitett térségek „fellazítását” (Bashford, 2014, 316-317. o.).

Jóllehet az átmenet-elméletet megalapozó tanulmányban Notestein a motiváció hiányára fogta a születéskorlátozás népszerűtlenségét, az elmélet ilyetén átlényegülésével már a homo economicus archetípusára támaszkodott, amely gazdasági racionalitásból szükségszerüen visszafogja termékenységét - ehhez csak az eszközöket kell számára biztositani.10 Míg az alkalmazott szférában kétség sem férhetett a belső ellentmondásokkal terhelt, módositott átmenetelmélet megbízhatóságához, addig akadémiai körökben az éppen felemelkedő és Talcott Parsons megfellebbezhetetlen tekintélyével szavatolt, az aktorok racionalitását hirdető strukturális funkcionalizmus (Id. Pokol, 1987) intellektuális védőhálóként bármilyen kritika felvetését ellehetetlenítette (Greenhalgh, 1996).

\section{A TUDOMÁNYTERÜLET FEJLÖDÉSÉVEL FOKOZÓDÓ EMPIRIKUS NYOMÁS}

A széles körben elfogadott elmélet „mézeshetei megközelítőleg 20 évig tartottak" (Kirk, 1996, 364. o.), és csak ezután jelentek meg az első kételyek. Nagy szerepet játszott ebben, hogy az ötvenes és hatvanas évek „baby boom”-ja épp „otthon” hazudtolta meg az átmenet lineáris lefolyását, sokak kiábrándulását okozva a notestein-i interpretációból (Reher, 2004). A kritikai hangokat

\footnotetext{
${ }^{10}$ A szemléletváltáshoz bizonyosan Notestein személyes benyomásainak változásai is hozzájárultak. Ebben a tekintetben kiemelkedik egy 1948-as távol-keleti expedíció, melynek során Notestein kutatótársaival arra lett figyelmes, hogy a falvak lakói hajlamosak lennének reprodukciójuk csökkentésére, ha a fogamzásgátló eszközök rendelkezésükre állnának. Egy későbbi interjúban Notestein így emlékezett vissza a történtekre: „Soha életemben nem kerültem olyan helyzetbe, amelyben annyira tehetetlennek éreztem volna magam." (idézi Reed, 1984, 305. 0.)
} 
viszont elnyomta az empiricizmus térnyerése." Másrészt az elmélet életben maradását a hatalmas összegekkel megtámogatott - Demény Pál (1988) találó kifejezésével - „családtervező ipar” felfutása is szavatolta. Ugyancsak Deményhez köthető az elmélet hivatásának egyik legérzékletesebb megragadása a korabeli viszonyok között: „Így minden eddiginél nagyobb szükség van a demográfiai átmenet elméletére, nemcsak a múlt megmagyarázására és a jövő előrejelzésére, hanem olyan racionális és hatékony politikák megfogalmazásának irányításához is, amelyek révén a termékenység mesterséges csökkenése idézhető elő” (Demeny, 1968, 503-504. o.).

Az elmélet fő tézisei az európai átmenet lefolyásának konszenzuális - és meglehetősen felületes - meggyőződéséből indultak ki (Coale and Treadway, 1986). Az akár egy sematizált ábrába is összefoglalható axiomatikus megállapítások ugyan „,papíron” jól mutattak, viszont „élesben”, a családtervezési programok gyakorlatba ültetésénél már nemcsak az európai sikerrecept transzferálhatóságát övezte bizonytalanság, hanem „kemény adatok” hiányában magát a demográfiai átmenet európai lefolyását is. Ez hívta életre 1963-ban a princetoni intézet igazgatói székében Notesteint követő, Ansley J. Coale nevével fémjelzett ún. európai termékenységi projektet (European Fertility Project, a későbbiekben EFP). Ugyan a projekt vizsgálati céljai között nem jelent meg explicit módon, a projekt harmadik mozgatórugója - egyben validációs eszköze - az európai átmenet okozati mechanizmusainak feltárása volt annak érdekében, hogy az aktuális harmadik világbeli túlnépesedést kezelni tudják. Ez pedig egyet jelentett a demográfiai átmenet elméletét övező legfontosabb hipotézisek tesztelésével. Az EFP eredményeit összefoglaló kötet (Coale and Watkins, 1986) egyik legterjedelmesebb fejezete is amolyan önigazolásként azzal a felütéssel indított, hogy a projektnek „egyértelmü jelentősége van nemcsak Európa, hanem a világ számára is" (Coale and Treadway, 1986, 31. o.).

A bő két évtizedet felölelő EFP alatt az esettanulmányok sorra igazolták a demográfiai átmenet elméletének azon sejtését, mely szerint a házas termékenység csökkenése egy visszafordíthatatlan folyamat kezdetét jelenti (Coale, 1986b). További fontos eredményként a projektben résztvevő demográfusok rámutattak, hogy a szomszédos, sokszor eltérő fejlettségű tartományok döntően együtt haladtak ebben az átmenetben. Különösen igaz volt ez a megállapítás azokra a térségekre, amelyek hasonló felekezeti, nyelvi vagy etnikai képet mutattak (pl.

\footnotetext{
" Ennek kapcsán sokatmondó Szreter (1996, 685. 0.) megjegyzése a demográfiai kutatások korabeli pozicionáltságáról: „A statisztikai elemzés nemcsak elterjedt és rutinszerü, hanem a hetvenes évektől szigorúan előirt lett mindazok számára, akik azt kívánták, hogy empirikus kutatásuk kellően <<tudományos〉> fogadtatásban részesüljön”.
} 
Oroszország nyugati részein a lettek, németek, lengyelek és egyéb nyugati nemzetiségek körében élő oroszok is a környezetükhöz hasonlóan alacsony termékenységgel rendelkeztek) (Anderson, 1986). Következésképpen a modernizáció fokmérőinek tartott és az addig determinisztikusan kezelt osztálykülönbségek, falu-város dichotómiák, munkaerőpiaci körülmények vagy az indusztrializáció mintázatai gyengén jósolták a termékenységi átmenet kezdetének időzítését, így az EFP eredményei szerint inkább a regionális léptéken megragadható kulturális különbségek termelték ki az európai átmenetek diverzitását. Frappánsan összegezve mindez annyit jelentett, hogy a termékenység (illetve sok esetben a nupcialitás) törésvonalai a kulturálisan egyveretű régiók között, és nem a régiókon belül húzódtak.12

Az új ortodoxiává előlépett princetoni nézeteket ért kritikák alapvetően módszertani jellegüek voltak, így a túlzott területi aggregáció és a projekt során használt, a reprodukciós magatartás szempontjából nem feltétlenül releváns társadalmi-gazdasági mutatók köré csoportosultak (Cummins, 2013). Az EFP módszertanát ízekre szedő tanulmányuk konklúziójában Brown és Guinanne (2007, 593. o.) ugyanakkor egy episztemológiai problémára irányították a figyelmet: „Feltáró projektként az EFP szokatlanul ambiciózus, gyümölcsöző és befolyásos volt. De félreolvasta a történelmet”. Ez a félreolvasás Thornton (2001, 451. o.) rávilágításában akkor jelentkezik a demográfiai vizsgálatokban, ha a térbeli variációt időbeli variációra cseréljük, ezáltal a térbeli heterogenitást homogén fejlődéssé változtatjuk. Ez a művelet teszi zökkenőmentessé egy 20. századi fejlődő ország azonosítását a 18. századi Nyugat-Európa viszonyaival, és ez teremti meg azt a látszatot, hogy az európai termékenységi átmenet megértésétől a túlnépesedés megértését is remélni tudjuk. Azzal, hogy az EFP ernyője alatt született tanulmányok a magasabb léptéki szinttel tulajdonképpen feláldozták a szubregionális egyenlőtlenségeket, végső soron ezt a puha taktikát választották ahhoz, hogy inkább az időben jelentkező különbségekre tereljék a figyelmet.

Jóllehet ez az episztemológiai állásfoglalás kiválóan illeszkedett az átmenet-elmélet evolúciós tipizálásához, a kultúra magyarázó tényezővé történő előléptetése, illetve az átmenet és modernizáció ok-okozati összefüggésének korábban közmegegyezés tárgyát képező - elvetése mégis annyira ellenkeztek

\footnotetext{
${ }^{12}$ Az EFP hozadékaként hirtelen előtérbe helyezett kultúra mint magyarázó tényező olyannyira ellenkezett a közgondolkodással, hogy a strukturális tényezők védelmében egy leplezetlenül ellentámadásként definiált demográfiai projekt is indult a nyolcvanas évek végén Patrick Galloway vezetésével (University of California Prussian Project). A kutatás beszámolójában a szerzők kifejezésre is juttatták, hogy a termékenységi átmenetben a gazdasági kauzalitás elvetése "mind az intuícióval, mind az elméleti elvárásokkal ellentétes" (idézi Szołtysek, 2007, 24. 0.).
} 
az átmenetről vallott közgondolkodással, hogy végső soron általános elbizonytalanodást okoztak (Bongaarts and Watkins, 1996). Az EFP így csak az átmenet irreverzibilis lefolyását igazolta, minden más tekintetben viszont „meglepő volt, hogy országról országra, a demográfiai átmenet elméletébe ágyazott hipotézisek tesztjei nem igazolták az elméletet” (Watkins, 1986, 436. o.). Ráadásul a demográfia központi polémiájához az EFP csak egy meglehetősen „vérszegény” konklúzióval tudott hozzájárulni: „Ha tanulságokat szeretnénk levonni a tizenkilencedik századi Európából és azokat a mostani országokba exportálni, akkor kézenfekvő a diverzitást kihangsúlyozni” (Watkins, 1986, 449. o.).

A kihangsúlyozott diverzitás intelme viszont leginkább csak a demográfiai átmenet elméletének univerzális receptjét veszélyeztette, a harmadik világbeli túlnépesedés körül fokozódó vitát nem tudta érdemben befolyásolni. Ebben a vitában döntően a fogamzásgátlás mellett elköteleződött demográfusok egyre defenzívebb álláspontba kerültek a föleg közgazdászokból verbuválódó modernizációs iskolával szemben. Utóbbi oldal lényegében az átmenet-elmélet eredeti interpretációját vette alapul, így az elsőként az ENSZ 1974-es népesedési világkonferenciáján elhangzott, a „fejlődés a legjobb fogamzásgátló” (Singh, 1988) mottójuk is Notestein kezdeti irányelveihez igazodott. Ezzel merőben ellentétes álláspontot képviseltek a kínálati oldalban beavatkozásokat sürgetők, mert „,bár a fejlődés és a társadalmi változás a kisebb családokat előnyben részesitő feltételeket teremtenek, mégis a fogamzásgátló a legjobb fogamzásgátló" (Robey et al., 1993, 65. o.). ${ }^{13}$

A vitából ugyan egyik oldal sem került ki győztesként - sőt inkább az álláspontok közeledése volt tetten érhető (Kaiser, 2001) - kétségtelen, hogy a családtervezési programok csak szerény mértékben befolyásolták a termékenységi átmenetek ütemét a harmadik világban (Tsui, 2001; Miller and Babiarz, 2016). A felfütött várakozásoktól elmaradt eredmények arra utaltak, hogy az európai tapasztalatból táplálkozó demográfiai átmenetet nehezen lehet tetszőleges társadalmakra vagy kultúrákra „ráerőltetni”. A küldetés azért is lehetett kudarcra ítélve, mert a némi eufemizmussal családtervezésnek keresztelt népességszabályozást az átmenet éllovasainak számító nyugati országok olyan innovációként próbálták exportálni, amelyet ők maguk soha nem próbáltak ki (Barrett et al., 2010).

${ }^{13}$ A dichotomikus szembeállást kitủnően példázta a Population and Development Review 1994-es számaiban kibontakozott vita (Id. Pritchett, 1994a, b; Knowles et al., 1994; Bongaarts, 1994). 


\section{A TERMÉSZETES TERMÉKENYSÉG KÉRDÉSKÖRE ÉS AZ ÁTMENET KÉT ÖSSZETEVÖJÉNEK KÖLCSÖNHATÁSA}

Jóllehet a modernizációs elmélet bukását a hetvenes években nem követte az időközben paradigmatikus beágyazottságra szert tett átmenet-elmélet „leváltása”, mégis a viták során elhasználódott és a demográfusok számára egyre kényelmetlenebbé váló koncepció meghaladására az egyik legkifizetődőbb taktika a termékenységi átmenetre való egyszerüsítés lett (van de Walle, 1992). Az új fogalom használata hiába tűnt divatosabbnak és a közgazdaságtan felivelő termékenységelméleteivel nagyobb összhangban levőnek, a demográfia elméleti útkeresését nem oldotta fel, sőt azt egy újabb kanyarral egészítette ki. A termékenységi átmenet konceptualizálásához ugyanis történeti kontextusban kellett felvázolni az átmenetet megelőző és az átmenet utáni populációk termékenységi rezsimjeinek jellemzőit. Az úttörő szerepet Louis Henry (1961) francia demográfus és az általa használt természetes termékenység fogalma (fécondité naturelle) érdemelte ki, ezzel újabb löketet adva a demográfiai időfolyam korszakolásához, melynek kulcseleme, egyben választóvonala a tudatosság lett. Ez ránézésre szemben állt az átmenet-elmélet azon premisszájával, mely a népi születéskorlátozó módszereket évszázadok óta ismertnek vélte (Notestein, 1945, 1953).14 Coale az EFP-s kutatás operacionalizálásához e két elméleti iránytű közös pontjaira támaszkodva dolgozta ki a kontrollált termékenységi rezsim elterjedésének három alapfeltételét (Coale, 1973). A projektben született eredmények annyiban mégis szembefordulást jelentettek a szellemi előzményekkel, hogy a tudatos születésszabályozás feltételét (ability) hangsúIyozó Henry-féle megközelítéssel, valamint az átmenet-elmélethez is köthető adaptációs (willingness) nézőponttal szemben az erkölcsi normák változását (readiness) megragadó harmadik feltételtől tették függővé a termékenységi átmenet kezdetét (Őri, 2018).

Hiába tűnt cizellált megközelítésnek Coale háromfeltételes modellje és engedett teret a reprodukciós stratégiák történeti folytonosságának, az átmenetelmélettel is rokonitható episztemológiai keretek az EFP munkaközösségét a gyakorlatban mégis egy minél precízebben meghatározható történeti fordulópont megtalálásának - vagy éppen felállításának - irányába sarkallták. Ilyen alapokra helyezkedve a korszakhatár adott tartományokon belül a nagyfokú

\footnotetext{
${ }^{14}$ Ezt a felismerést egy felmérés is támogathatta, mely szerint a bronxi családtervezési klinikára érkező európai bevándorló nők 95\%-a rögtön a házassága után alkalmazott már születéskorlátozást a modern fogamzásgátlási eszköz felajánlása előtt (Stix and Notestein, 1934).
} 
tudatosságot feltételező paritás-specifikus stopping magatartás térnyerésének pillanata lett (Watkins, 1986). ${ }^{15}$ A logikai koherencia fenntartásának tulajdonítható, hogy az EFP-ből többen is teljesen elvetették a családméret-szempontú születésszabályozás lehetőségét pretranzíciós népességek esetén, így azt a többség számára idegen magatartásnak (Knodel and van de Walle, 1979), vagy bizonyos szűk társadalmi csoportokra szorítkozva (pl. zsidóság, városi arisztokrácia), a társadalmi összképet tekintve jelentéktelen tényezőnek tartották (Livi Bacci, 1986; Cleland, Wilson, 1987). Coale ugyan a stoppingot a természetes termékenység rezsimével összeegyeztethetőnek vélte, bizarr véleménye szerint ez a magatartás mégsem terjedhetett el széleskörüen, mert az ezt alkalmazók mindig „kihaltak”: „Ez egy halálos mutáció társadalmi megfelelője lehetett, amely ismétlődően megjelenik, de soha nem marad fenn.” (Coale, 1986b, 22. o.). Feltehetően a Henry-féle definícióhoz való túlzott ragaszkodásnak tulajdonítható, hogy az EFP egy olyan előfeltevést betonozott be, amely pretranzíciós népességeknél zárójelbe helyezte a fogamzásgátlás lehetőségét (Santow, 1995). Ez a hallgatólagos konszenzus vezetett a kultúra és ágencia (agency) szétválasztásán alapuló természetes és kontrollált termékenység dichotómiájához (Carter, 1995; Saito, 2015).

A termékenység történeti kontrolljának diszkontinuitása könnyen idomult a demográfiai átmenet elméletéhez, amely belső logikájából fakadóan épp e két korszakot, illetve a köztük lévő átmenetet ragadta meg. Nem véletlen, hogy az elmélet prototípusai is mind e három szakasz leírására vállalkoztak, és ez a formula rögzült akár az EFP által meghatározott évtizedek, akár az ezredfordulót követő demográfiai szakirodalomban (Cowgill, 1963; Watkins, 1986; Casterline, 2003). A standard háromosztatú lefolyás további felbontásához viszont nincs több kapaszkodónk. Csupán arra a tényre támaszkodhatunk, hogy kortól függetlenül az átmenet leírásánál szinte mindenütt fontosnak tartották kiemelni, hogy magát az átmenetet jelölő második szakasz korántsem homogén jellegü, hanem annak elejét a halandóság, majd későbbi lefolyását a termékenység csökkenése határozza meg. Ennek lett az eredménye, hogy szofisztikáltságtól függően a köztes szakaszt felbontják-e két vagy akár több részre (ld. Chesnais, 1990). Kevés kivételtől eltekintve (pl. Andorka, 2006; Tomka, 2009) Magyarországon többnyire a négyszakaszos demográfiai átmenet terjedt el, amely csak megjelenítésében különbözött az eredeti elmélet lényegi elemeitől (vö. Valkovics, 1982; Hablicsek, 1995; Kovács, 2002). A változatos kivitelezésű ábrák

${ }^{15}$ A történeti termékenységi mintázatok kontinuitására jobban reflektáló spacing jelentőségére vonatkozóan Id. Anderton and Bean, 1985; Lee and Wang, 1999; van Bavel, 2004. 
alapján (1. ábra) a két egyensúlyi állapot közötti szakasz felbontása amolyan kutatói hóbortnak is tűnhet, - például Szentgáli (1991) az eredeti hármas felosztás további szakaszolását „ízlés” kérdésének tekinti - de valójában a demográfiai átmenet egyik kulcsdilemmája húzódik meg a háttérben. Ugyanis minél jobban széttagoljuk a középső szakaszt, annál inkább törvényszerüsítjük, hogy a halandóság javulása megelőzte a termékenység csökkenését az átmenetben.

\section{1. ábra: Változatok egy témára - a demográfiai átmenet modelljei}

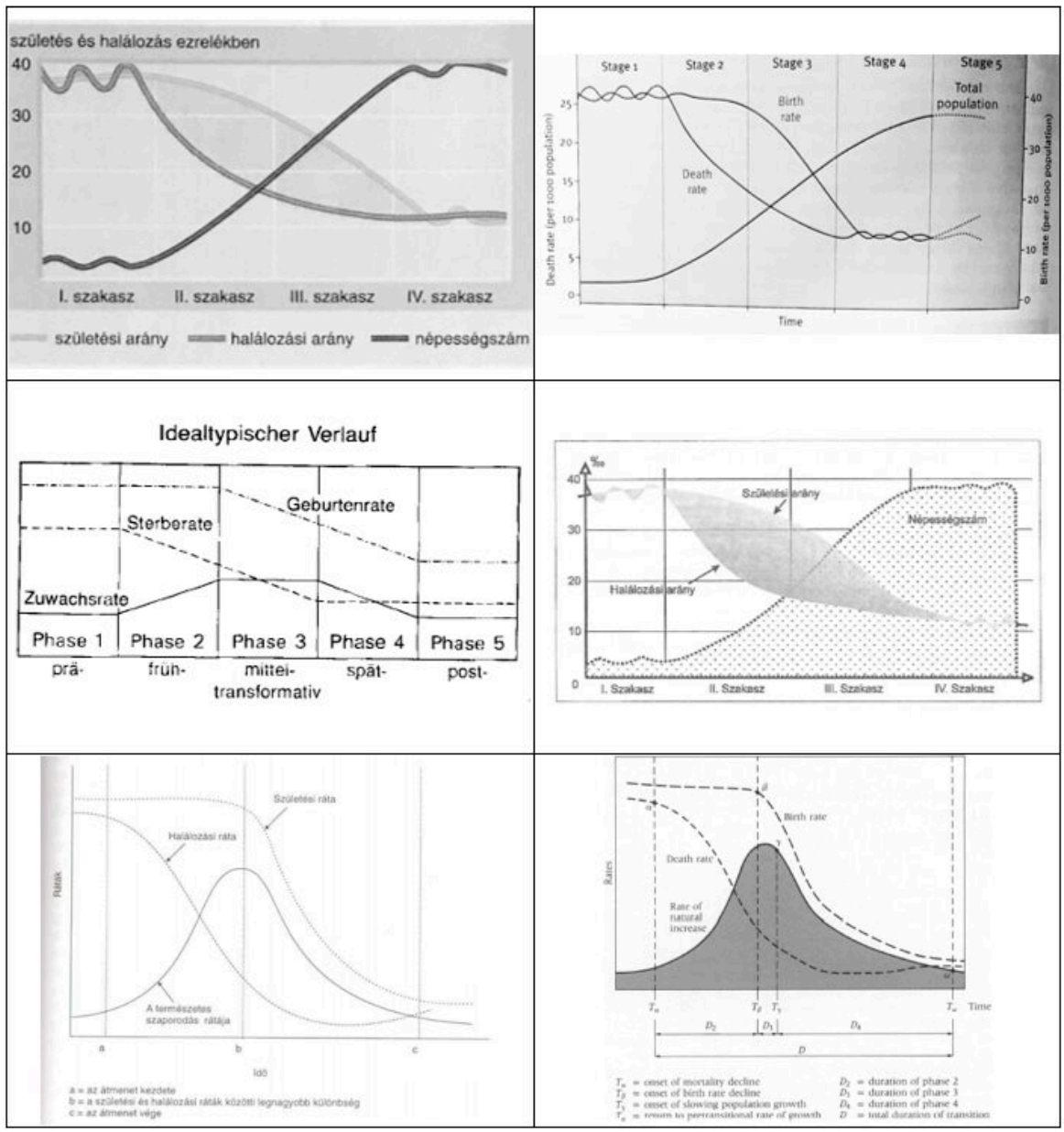

Megjegyzés: Az elmélet szellemi beágyazottságának értelmében az x tengelyen jelölt idő akár a gazdasági fejlettséggel vagy a modernizáció előrehaladottságával is helyettesithető.

Forrás: bal felső (Jónás et al., 2011); jobb felső (Jones, 2009, 60. 0.); bal középső (Bähr, 1997, 249. 0.); jobb középső (Kovács, 2002, 25. 0.); bal alsó (Livi-Bacci, 1999 [1992], 131. 0.); jobb alsó (Chesnais, 1990, 328. 0.). 
Az átmenet-elmélet hajnalán e két tényező irányítottságához még kevés kétség férhetett: „A csökkenő halálozási ráták egyszerre növelték az ellátandó családméretet és csökkentették a további szülések indítékát” (Notestein 1953, 16. o.). Ráadásul Davis (1963) a többfázisú válasszal (multiphasic response) a történeti termékenység- és halandóságcsökkenés kauzális viszonyát is konceptualizálta, ami kiválóan illeszkedett a növekedési olló kinyílását jelző második szakasz háttérelméletének univerzális szerepkörébe. Csakhogy időközben a családtervezési ipar egyik keserü felismerése, mely szerint a halandóság és a termékenységi szintek egymástól függetlenül váltakoznak a térben, meggátolta ebben (Cleland, 2001). A kurrens tapasztalat történeti esetekre való rávetülésének nyomán az átmenet-elmélet egyik évtizedes tartópillére került hirtelen össztűz alá. Ezek általában a csecsemőhalandóság és termékenység közötti gyenge korrelációs kapcsolattal (Cleland and Wilson, 1987), a mortalitás és termékenység közötti oksági láncolat irányítottságának (van de Kaa, 1996), vagy magának a kauzalitás tényének (Garrett et al., 2001) megkérdőjelezésével növelték a kételkedők táborát. Ezt az EFP berkeiből származó páneurópai empírián kívül (ld. van de Walle, 1986) több olyan vizsgálat is megalapozta, amelyek szerint a termékenységi átmenet akár évszázados különbséggel is megelőzhette a halandósági szintek esését (Id. USA esetén Haines, 1998; Franciaországra Cummins, 2013; Angliára Teitelbaum, 1984). Ehhez hasonló példákban Magyarország sem szerénykedhet, hiszen az angolszász szakirodalomban is előszeretettel hivatkozott Ormánságban már a 18. században kiterjedt paritás-specifikus születéskorlátozás volt a bevett gyakorlat, holott azt az átmenet-elmélet értelmében a halandóság nem indokolta volna (Andorka, 1970; Coale, 1986a; Vasary, 1989). ${ }^{16}$

A sokasodó empirikus muníció kereszttüzében az ellen-narratívák leginkább csak az átmenet-elmélet ösztönösségére szorítkozhattak: „Ha volt egyetlen vagy kitüntetett oka a termékenységi átmenetnek, ésszerű lenne azt a mortalitás csökkenésének tulajdonítani, amely a destabilizáció fő okozója volt” (Kirk, 1996, 379. o.). Tegyük hozzá, nem véletlenül. A korszak módszertani standardjait alapjaiban meghatározó EFP által szállított empírián ugyanis nehezen lehetett fogást találni, csakhogy - Mason (1997, 447. o.) érvelésében - „a partikuláris eredményeket [...] túlságosan is szívre vettük”, megfeledkezve arról, hogy a demográfiai átmenet kezdetén mindenütt népességnövekedés realizálódott, ami halandóságcsökkenés nélkül aligha lett volna kivitelezhető. A termékenység

\footnotetext{
${ }^{16}$ Érdemes megjegyezni, hogy a 18. századi termékenységi elemzéseket rendszerint - adathiányra való tekintettel - nem kísérték hasonló szintű halandóságelemzések.
} 
és halandóság okozati viszonya azonban hiába tűnt „ésszerűnek”, statisztikai bizonyítása már csak a rengeteg lehetséges közvetítő tényező hatása miatt is megugorhatatlan akadálynak tünt (Cleland, 2001). Ennek következtében az EFP konklúzióit elutasítók, valamint az új irányokat keresők számára maradt a demográfiai átmenet makroperspektivikus és holisztikus olvasata, amelyben a termékenység változása magától értetődő természetességgel követi le a mortalitás csökkenését (Id. ehhez példaként Rees, 2009 enciklopédiai szócikkét a demográfiáról). Sőt, a kapcsolat olyannyira mechanisztikus olvasataival is találkozhatunk, amelyek értelmében a jelenkori halandóság esetleges ismételt emelkedése a születési ráta emelkedését is magával vonná - igaz, a több fázisnak megfelelően mindig időbeli késéssel (Dyson, 2001).

Kétségtelen, hogy a demográfiai átmenet elméletéhez visszakanyarodó koncepció reneszánszához nagyban hozzájárult David Reher munkássága. A vitapontról vallott véleményét jól summázza a következő idézet: „Sehol a világon, függetlenül az időbeli periódustól, a modernizáció fokától vagy a gazdagság szintjeitől, a termékenység változása nem következett be azt megelőző, jelentős mortalitásváltozás nélkül” (Reher, 2004, 25. o.). Megjegyzendő, hogy az érezhetően túlzó megállapítást egy későbbi tanulmányában némileg azzal finomította, hogy a halandóság csökkenése a termékenységi átmenetet „szinte mindenütt” megelőzte (Reher, 2011, 12. o.). Mindezzel együtt Reher mindvégig következetes képviselője maradt annak az álláspontnak, hogy a demográfiai átmenet valódi kulcsmomemtuma a csecsemőhalandóságban bekövetkezett javulásban ragadható meg (Reher, 1999, 2019). ${ }^{17}$ A jelenlegi szakirodalmi konszenzus ehhez képest némileg árnyaltabb álláspontot követ, melynek értelmében a halandóság csökkenése önmagában nem volt elégséges a termékenységi átmenethez, viszont a gyermekek túlélési esélyében történt drámai javulás nélkül a termékenységi fordulat sem következett volna be (Tsuya et al., 2010; Dribe et al., 2014).

\section{A MINDENT TÚLÉLŐ ELMÉLET}

A második világháború és 1980-as évek között „,valószínűleg nem volt olyan kutatási kérdés, amely gyakrabban jelent volna meg a demográfiai irodalomban, mint a demográfiai átmenet elméletei és magyarázatai” (Friedlander et al., 1999, 494.

\footnotetext{
${ }^{17}$ Amennyiben a gyermekhalandóság vizsgálatát nem szükítjük le a csecsemőhalandóság témakörére, még meggyőzőbb bizonyítékokat találunk a halandóság, és az arra adott reprodukciós magatartás kölcsönhatására (Id. Sánchez-Barricarte, 2017; Gortfelder and Puur, 2020).
} 
o.). Sőt, párhuzamosan az EFP-ből érkező eredmények publikálásával, a nyolcvanas évek elején egy felívelés is történt a demográfiai átmenet fogalmának szakirodalmi előfordulásában (van de Walle, 1992). A gyakori használatot viszont már nem a rutinszerű hivatkozások, hanem az elmélet létjogosultságát firtató viták okozták. Az átmenet-elmélet ugyanis nem volt teljes, hiszen a skála hiánya, a termékenység és halandóság mérőszámainak elkendőzése, valamint a szakaszok homályos hossza inkább csak kételyt és bizonytalanságot szült az egyre precízebb adatokkal operáló demográfiai kutatások számára. Ráadásul a tényezőcsoportok változásának egysíkú notestein-i interpretációi már nem feleltek meg az interdiszciplinaritást és posztmodern relativizmust előtérbe helyező korszellemmel. Így például a nagycsaládos modell és az individualizmust díjazó urbánus közeg inkompatibilitásának kidomborítása már bizonyosan kevés volt ahhoz, hogy a heterogén utakat bejárt termékenységi átmenetek teljes spektrumát lefedje. ${ }^{18}$

A legnagyobb problémát viszont az jelentette, hogy a történelmi jelenségek diverzitását érzékeltető kutatások gyorsabban halmozódtak fel, mint ahogy azt az átmenet-elmélet fel tudta volna szívni (Szołtysek, 2007). Mindez megfejelve a modernizációs paradigma alkonyával rövidesen egyértelművé tette az elmélet diagnózisát: „Mostanra sok körben bevett vélekedés, a demográfián belül és túl, hogy a demográfiai átmenet elméletének halála közeleg” (Hirschman, 1994, 213. o.) - azonban nincs tudomásunk olyan korszakosnak tekinthető tudományos munkáról, amely az elmélet kegyelemdöfését jelentette volna. A szakirodalmi kutatás alapján inkább az átmenet-elmélet lassú, de biztos kikopása volt tetten érhető, melyet a folyamatosan változó szakpolitikai kontextus is indokolt. Ide sorolhatjuk a hidegháború végével kifulladt harmadik világbeli népességszabályozási gyakorlatot (szinkronban a népességbomba „besülésével”), illetve az új évezred kezdetétől egy jelentős szakpolitikai hangsúlyeltolódást a neomalthusiánus megfontolásoktól a nők reprodukciós jogainak irányába (ld. bővebben Eager, 2004). Az átmenet-elmélet térvesztését érzékeltetendő van de Kaa (1996) terjedelmes cikkében érvelt amellett, hogy a tudomány fragmentációjával összhangban a totalizáló elméletek ideje lejárt, így a demográfiai átmenetnek is már csak alnarratíváiról beszélhetünk, amelyek az átmenet egy-egy szegmensét a strukturális, kulturális vagy egyéb irányzatok szürőjén keresztül „mesélik el”. Ám olyan véleménnyel is lehet találkozni, amely az elmélet hanyatlását és az alnarratívák domaninciáját csupán egy episztemológiai válság eufemizálásának gondolja (Szołtysek, 2007).

\footnotetext{
${ }^{18}$ Megjegyzendő, hogy ezt a magyarázatot Notestein (1953) sem tudta minden esetben érvényesíteni, így ő maga is értetlenül állt a 18. századi, Franciaország rurális térszínein kibontakozó termékenységi átmenet előtt.
} 
A demográfiának viszont továbbra is szüksége volt azokra a népességváltozást megragadni képes konceptuális tengelyekre, amelyek mentén a demográfiai átmenet elmélete is kibontakozott. Ebben a helyzetben a kutatók számára két kézenfekvő stratégia maradt. Mint korábban említésre került, az egyik irányzat az átmenetet nemes egyszerüséggel a termékenység görbéjére redukálta. A másik kutatói irány viszont úgy tartotta, hogy a termékenységi átmenetet nem lehet izoláltan kezelni, mivel az csakis a halandósággal és népességnövekedéssel együtt érthető meg (Cleland, 2001). Ahogy Wilson és Airey $(1999,125$. o.) tanulmányukban rámutatnak: „Az átmenetet egy növekedési epizódként kell megérteni, semmint a termékenység csökkenéseként". Hasonlóan érvelt Hirschman (1994, 28. o.): „Ahelyett, hogy megkérdeznénk és egy egyszerű választ várnánk arra vonatkozóan, hogy miért csökkent a termékenység, az alternatíva az a kérdés lehet, hogy a demográfiai egyensúly hogyan állt vissza a halandóság csökkenése után”. Mint látható, az átmenet holisztikus jellegét és a demográfiai egyensúlyt nyomatékosító érvelések végeredményben csak újracímkézték az átmenet-elméletet. A különbséget csupán az jelentette, hogy ezek a tanulmányok paradox módon már nem az „idejétmúlt” Notesteint vették hivatkozási alapul, hanem messzebbre, egészen Malthusig nyúltak vissza.

Az élelmiszertermelés és a népesség növekedési ütemének diszkrepanciájából eredeztetett, azóta „időtlenné vált” (Robbins, 1998, 243. o.) malthusi formula egységnyi élelmiszerre egyre több embert vizionált. Malthus ezt a kölcsönhatást és az abból predesztinálható disztópiát determinisztikus jellegünek, az élővilág természetes hajlamából eredőnek tekintette. Meglátása szerint ugyanis pont ez az emberiségbe kódolt ösztön tartotta nyomorban a társadalom alsóbb osztályait: „Ha a népesség felszaporodott csaknem végső határáig az élelemnek, természetesen az összes előző és tényleges akadályok növekedett erővel fognak működni” (Malthus, 1902 [1826], 14. o.). A „túlszaporodásnak” végül az önmegtartóztatáson alapuló negatív-, valamint a háborúkat és járványokat eredményező pozitív fékek láncreakciója vet véget. Így a malthusiánus katasztrófaként aposztrofált drasztikus halálozási válsággal lehetőség nyílik az egyensúlyi állapot ismételt elérésére. Az élelem színvonala alá süllyedt lakosság egyszersmind a gyarapodás újabb hullámának ad teret - természetesen az egyensúlytalanság újabb bekövetkeztéig. Ez a malthusi ciklikus együttmozgás a homeosztázis elvén alapul (Johnson-Hanks, 2008).

A homeosztatikus demográfiai rezsimek sajátossága, hogy adott népességcsoport demográfiai karaktere az erőforrásaihoz mérten alakul, olyan mechanizmusok érvényesülésével, melyek hosszú távon kiegyenlítik a fertilitási és mortalitási rátákat. Ez a szemlélet rövidtávon nem zárja ki bizonyos mértékủ inga- 
dozások elvi lehetőségét a termékenység és halandóság viszonylatában, viszont hosszabb időtávon - az erőforrások nivelláló hatásának következményeként - tényállásként fogadja el a két összetevő egymáshoz történő igazodását. Jóllehet a predeclin korszakra vonatkozó kutatások gyenge hátszelet kaptak kvantitatív oldalról, empirikus következtetéseik rendszerint a homeosztázis történelmi fennállásának irányába konvergáltak (Lesthaeghe, 1980; Fernihough, 2013). Ugyanakkor ezen kutatásokat gyakran érte az a kritika, hogy levezetésük zsigeri interpretációk sorozatán, eredményeik pedig mesterkélt, közvetítő változókon alapult. Utóbbi vádpontra próbált rácáfolni Ronald D. Lee, aki a homeosztázis direkt kimutathatósága érdekében vizsgálatának középpontjába a sűrüség-függést helyezte - méghozzá az állati populációk analógiája alapján. Eredményei a népességnövekedés és a „benépesültség” mértékének gyenge korrelációs kapcsolatát hozták, de ezek nem tántorították el a szerzőt homeosztázis melletti elköteleződésétől, mivel „enélkül képtelenek vagyunk megmagyarázni a népesség nagyságát és változását az idő múlásával, hacsak nem vesszük számba az események értelmetlen kronológiáját egészen az emberiség kezdetéig - bármikor is volt az" (Lee, 1987, 459. o.).

Az idézet kiválóan rávilágít a demográfiai gondolkodás egyensúlyi fétisére, egyúttal támpontot nyújt annak megértéséhez, hogy a kvantitatív bizonyítékokhoz szokott demográfusok számára mégis miért lehet tolerálható a homeosztázis elnagyolt episztemológiai kerete. A kulcs valószínűsithetően a múlt holisztikus megértésének igényében rejlik, így talán nem meglepő, hogy a homeosztázis-kutatások az empirikus adatokkal már kellően dokumentált 19-20. századi időszaktól nagyvonalúan eltekintenek (ld. Wilson, 2003). Jobban belegondolva azonban a homeosztázis gondolata igenis végigkísérte a globális demográfiai olló kinyílásának időszakát - mégpedig a demográfiai átmenet-, illetve a többfázisú válasz elméletének képében (Johnson-Hanks, 2008). Valóban, az egyensúly mindkét elméletet omnipotens demográfiai erőként szövi át: a demográfiai átmenet elméletében az átmenetiség csakis a kezdeti és végső egyensúly vonatkozásában nyerheti el értelmét, Davis többfázisú válasz elméleténél pedig a kiváltott válaszokat minden esetben az egyensúlyi állapottól való eltérések eredményezik.

Szűkebb értelmezésben a homeosztázisra koncentráló kutatások továbbra is a pretranzíciós időkben mozognak otthonosan, de a „demográfiai átmenet végének közeledte” a komfortzóna elhagyásához vezethet. Így azokban az országokban, melyekben a termékenység a halandóság szintjére süllyedt, a homeosztázis akár alkalmas elemzési keretet is nyújthat - igaz, leginkább térben és időben kiterjesztett, a generalizálás igényével fellépő vizsgálatokhoz (Coleman and 
Rowthorn, 2011; Billari and Dalla-Zuanna, 2013). Alacsonyabb léptéken, a jelenkori adatdömping kontextusában viszont a homeosztázis nem több egy pillanatfelvételnél; amit rögtön a következő pillanatban már a szubpótló termékenység stádiuma követ.

\section{ÖSSZEGZÉS}

Ugyan Notestein 1945-ben nem kifejezetten a demográfiai átmenetiség megragadására vállalkozott, kanonizált elmélete mégis évtizedekre az erről vallott demográfiai közgondolkodás szervezőelve lett. Nem kérdés, hogy a modell könnyed fogyaszthatósága alapjaiban megágyazott az elmélet felemelkedésének, melyhez a második világháborút követő új világrend társadalompolitikai feltételei is ösztönzőleg hatottak. Ezzel párhuzamosan az alapvetően nemzeti keretek között mozgó demográfiai kutatások fókusza ugyancsak a globális léptékre szegeződött (Ehmer, 2004; Teitelbaum and Winter, 1985). Az átmenet megértése ezt követően csak a globális színtéren vált elképzelhetővé, így az átmeneten már túljutott országok a lemaradó országok demográfiai viszonyainak kontrasztjában érdemelték ki a „fejlett” jelzőt. Ezzel szemben az átmenetben „,hátul kullogók” - ahol „lényegében az események európai lefolyását feltételezzük" (Notestein, 1945, 56. o.) - népesedésének jövője a történelem félreolvasásának segítségével élőben megtapasztalhatóvá vált. Az egyik csoport a múltját, míg a másik a jövőjét tudhatta meg azzal, ha megfigyeli a tőle akár több ezer kilométerre fekvő régió demográfiai viszonyait. Mindennek „áraként” az elmélet óhatatlanul is magán viselte a teleologikus jegyeket, alkalmazott tipizálása pedig szellemtörténeti és politikai beágyazottságának tulajdoníthatóan elkerülhetetlenül evolúciós szempontokat érvényesített.

Ahogy arra a tanulmány második része rámutatott, az átmenet-elmélet térvesztését mégsem a Nyugatot követendő példaként beállitó normatív alapok, hanem leginkább az empirikus vizsgálatok és módszertani megközelítések révén felszínre került ellentmondások eredményezték. Ráadásul a modell egyre kevésbé tűnt alkalmasnak a szofisztikált kvantitatív követelményeket támasztó demográfia elméleti keretének főszerepére. Ugyan az „átmenetük végéhez” ért országok demográfiai képlete újra előtérbe hozta az átmenet-elméletben meghúzódó homeosztatikus mechanizmusok érvényesülésének lehetőségét, a homeosztázis túlságosan is elnagyoltnak tűnt ahhoz, hogy akár a jelenlegi, akár a történeti demográfiai változások időtálló keretezése maradjon. 
A homeosztázis bemutatása a tanulmányban továbbá felszínre hozta és egyértelműsitette az átmenet-elmélet malthusiánus jegyeit. Így az elméletbe kódolt lineáris kontinuum mellett az alkalmazkodóképesség és egyensúly demográfiai ideái világítanak rá a leginkább a demográfiai átmenetiségről vallott tudományos gondolkodás felvilágosodásban gyökerező és Malthustól egészen a modern demográfia megszilárdulásáig tartó folytonosságára. Mindezek fényében nem túlzás azt a végkövetkeztetést levonni, hogy Notestein és a princetoni hivatal munkatársai csupán precízebb formát adtak egy mélyen gyökerező intellektuális diskurzusnak, kiegészítve azt az aktuális népességpolitikai kívánalmaknak megfelelően.

Az átmenet-elmélet alternatíváiként kínálkozó megközelítések (egyelőre) térben és időben is behatároltak, így a globális népességnövekedés legfontosabb korszakát manapság is csak a demográfiai átmenet (a kikopásra itélt „elmélete” utótag nélkül) képes egészében megragadni. Ez azonban sokat finomodott az elméletalkotókhoz képest, hiszen mostanra közmegegyezés tárgya lett, hogy nincsenek olyan konzisztensen megfogalmazható makrováltozások, amelyek megjósolhatnák a termékenységi átmenet kezdetét vagy sebességét (Morgan and Rybinska, 2019). Ennek tükrében a demográfiai átmenet már nem elméletként, hanem inkább deskriptív keretrendszerként funkcionál, melyben úgy tünik, hogy a termékenység és halandóság determinánsai mindig más utat követnek (Kreager, 2015), viszont hosszú időtávon általában ugyanoda vezetnek (Reher, 2004). A megváltozott tudományos kritériumok között - minden leegyszerűsítése és pontatlansága ellenére - Demény Pál definíciója tűnik a leginkább időtállónak: „Hagyományos társadalmakban a termékenység és a mortalitás magas. Modern társadalmakban a termékenység és mortalitás alacsony. Közöttük van a demográfiai átmenet" (Demeny, 1968, 502. o.). 


\section{IRODALOM}

Anderson, B. A. (1986). Regional and Cultural Factors in the Decline of Marital Fertility in Western Europe. In A. J. Coale and S. C. Watkins, (Eds.), The Decline of Fertility in Europe: The Revised Proceedings of a Conference on the Princeton European Fertility Project (pp. 293-313). Princeton: Princeton University Press.

Anderton, D. L. and Bean, L. L. (1985). Birth Spacing and Fertility Limitation: A Behavioral Analysis of a Nineteenth Century Frontier Population. Demography, 22(2), 169-183.

Andorka R. (1970). Születéskorlátozás az Ormánságban a 18. század vége óta. (A születésszabályozás elterjedésének hatása egy etnikai egység, az Ormánság népességstruktúrájának történeti alakulására.). Demográfia, 13(1-2), 73-85.

Andorka R. (1987). Gyermekszám a fejlett országokban. Budapest: Gondolat.

Andorka R. (2006). Bevezetés a szociológiába. Budapest: Osiris.

Barnes, T. J. (2004). Placing ideas: genius loci, heterotopia and geography's quantitative revolution. Progress in Human Geography, 28(5), 565-595.

Barrett, D., Kurzman, C. and Shanahan, S. (2010). For Export Only: Diffusion Professionals and Population Policy. Social Forces, 88(3), 1183-1207.

Bashford, A. (2014). Global Population: History, Geopolitics, and Life on Earth. New York: Columbia University Press.

Bähr, J. (1997). Bevölkerungsgeographie: Verteilung und Dynamik der Bevölkerung in globaler, nationaler und regionaler Sicht. Stuttgart: Ulmer.

Bálint L. (2016). Mennyire illeszkedik a magyar halandóság alakulása az epidemiológiai átmenet elméleteihez? Demográfia, 59(1), 5-57.

Billari, F. C. and Dalla-Zuanna, G. (2013). Cohort Replacement and Homeostasis in World Population, 1950-2100. Population and Development Review, 39(4), 563-585.

Blaut, J. M. (1993). The Colonizer's Model of the World: Geographical Diffusionism and Eurocentric History. New York: The Guilford Press.

Bongaarts, J. (1994). The Impact of Population Policies: Comment. Population and Development Review, 20(3), 616-620.

Bongaarts, J. and Watkins, S. C. (1996). Social Interactions and Contemporary Fertility Transitions. Population and Development Review, 22(4), 639-682.

Bourdieu, P. (2002 [1994]). A gyakorlati észjárás: A társadalmi cselekvés elméletéröl (fordította Berkovits B.). Budapest: Napvilág Kiadó.

Brown, J. C. and Guinanne, T. W. (2007). Regions and time in the European fertility transition: problems in the Princeton Project's statistical methodology. Economic History Review, 60(3), 574-595.

Burger, O. and DeLong, J. P. (2016). What if fertility decline is not permanent? The need for an evolutionarily informed approach to understanding low fertility. Philosophical Transactions of the Royal Society B: Biological Sciences, 371(1692), 20150157.

Caldwell, J. C. (1997). The Global Fertility Transition: The Need for a Unifying Theory. Population and Development Review, 23(4), 803-812.

Carter, A. T. (1995). Agency and fertility: For an ethnography of practice. In S. Greenhalgh, (Ed.), Situating fertility: Anthropology and demographic inquiry (pp. 55-85). Cambridge: Cambridge University Press. 
Casterline, J. B. (2003). Demographic Transition. In P. Demeny, and G. McNicoll, (Eds.), Encyclopedia of Population (pp. 210-216). New York: Macmillan Reference.

Chesnais, J-C. (1990). Demographic Transition Patterns and Their Impact on the Age Structure. Population and Development Review, 16(2), 327-336.

Cleland, J. (2001). The Effects of Improved Survival on Fertility: A Reassessment. Population and Development Review 27(Supplement), 60-92.

Cleland, J. and Wilson, C. (1987). Demand Theories of the Fertility Transition: An Iconoclastic View. Population Studies, 41(1), 5-30.

Coale, A. J. (1973). The Demographic Transition Reconsidered. In International Population Conference, Liège, 1973, vol. 1 (pp. 53-72). Liège: International Union for the Scientific Study of Population.

Coale, A. J. (1986a). Preface. In A. J. Coale and S. C. Watkins, (Eds.), The Decline of Fertility in Europe: The Revised Proceedings of a Conference on the Princeton European Fertility Project (pp. xix-xxii). Princeton: Princeton University Press.

Coale, A. J. (1986b). The Decline of Fertility in Europe since the Eighteenth Century as a Chapter in Human Demographic History. In A. J. Coale and S. C. Watkins, (Eds.), The Decline of Fertility in Europe: The Revised Proceedings of a Conference on the Princeton European Fertility Project (pp. 1-30). Princeton: Princeton University Press.

Coale, A. J., Treadway, R. (1986). A Summary of the Changing Distribution of Overall Fertility, Marital Fertility, and the Proportion Married in the Provinces of Europe. In: A. J. Coale and S. C. Watkins, (Eds.), The Decline of Fertility in Europe: The Revised Proceedings of a Conference on the Princeton European Fertility Project (pp. 31-181). Princeton: Princeton University Press.

Coale, A. J. and Watkins, S. C. (Eds.) (1986). The Decline of Fertility in Europe. The Revised Proceedings of a Conference on the Princeton European Fertility Project. Princeton: Princeton University Press.

Coleman, D. and Rowthorn, R. (2011). Who's Afraid of Population Decline? A Critical Examination of Its Consequences. Population and Development Review, 37(Supplement), 217-248.

Connelly, M. (2003). Population Control Is History: New Perspectives on the International Campaign to Limit Population Growth. Comparative Studies in Society and History, 45(1), 122-147.

Connelly, M. (2008). Fatal Misconception: The Struggle to Control World Population. Cambridge-London: The Belknap Press of Harvard University Press.

Cowgill, D. O. (1963). Transition Theory as General Population Theory. Social Forces, 41(3), 270-274.

Critchlow, D. T. (1999). Intended Consequences: Birth Control, Abortion, and the Federal Government in Modern America. New York: Oxford University Press.

Cummins, N. (2013). Marital fertility and wealth during the fertility transition: rural France, 1750-1850. Economic History Review, 66(2), 449-476.

Czirfusz M. (2020). Népesség- és településföldrajz a gimnáziumban - szemléletváltási lehetőségek. GeoMetodika, 4(3), 49-59.

Davis, K. (1945). The World Demographic Transition. The ANNALS of the American Academy of Political and Social Science, 237(1), 1-11. 
Davis, K. (1956). The Amazing Decline of Mortality in Underdeveloped Areas. The American Economic Review, 46(2), 305-318.

Davis, K. (1963). The Theory of Change and Response in Modern Demographic History. Population Index, 29(4), 345-366.

Dányi D. (1977). Regionális fertilitási sémák Magyarországon a 19. század végén. Demográfia, 20(1), 56-87.

Dányi D. (2000). Demográfiai átmenetek (Valóság, tudomány, politika). Demográfia, 43(2-3), 231-251.

Demeny, P. (1968). Early Fertility Decline in Austria-Hungary: A Lesson in Demographic Transition. Daedalus, 97(2), 502-522.

Demeny, P. (1988). Social Science and Population Policy. Population and Development Review, 14(3), 451-479.

Dribe, M., Oris, M. and Pozzi, L. (2014). Socioeconomic status and fertility before, during, and after the demographic transition: An introduction. Demographic Research, 31, 161-182.

Dyson, T. (2001). A partial theory of world development: the neglected role of the demographic transition in the shaping of modern society. International Journal of Population Geography, 7(2), 67-90.

Eager, P. W. (2004). Global Population Policy: From Population Control to Reproductive Rights. London: Routledge.

Ehmer, J. (2004). Bevölkerungsgeschichte und historische Demographie 1800-2000. München: Oldenbourg Wissenschaftsverlag.

Ehrlich, P. R. (1968). The Population Bomb. New York: Ballantine Books.

Fernihough, A. (2013). Malthusian Dynamics in a Diverging Europe: Northern Italy, 1650-1881. Demography, 50(1), 311-332.

Frey, M. (2011). Neo-Malthusianism and development: shifting interpretations of a contested paradigm. Journal of Global History, 6(1), 75-97.

Friedlander, D., Okun, B. S. and Segal, S. (1999). The Demographic Transition Then and Now: Processes, Perspectives, and Analyses. Journal of Family History, 24(4), 493-533.

Garrett, E., Reid, A., Schürer, K. and Szreter, S. (2001). Changing Family Size in England and Wales. Place, Class and Demography, 1891-1911. Cambridge: Cambridge University Press.

Girard, A. (1982). Adolphe Landry et la démographie. Revue française de sociologie, 23(1), $111-126$.

Gortfelder, M. and Puur, A. (2020). Survival and sex composition of offspring: Individual-level responses in the quantum and tempo of childbearing during the demographic transition. Population Studies, 74(2), 161-177.

Graham, E. (2000). What Kind of Theory for What Kind of Population Geography? International Journal of Population Geography, 6(4), 257-272.

Greenhalgh, S. (1996). The Social Construction of Population Science: An Intellectual, Institutional, and Political History of Twentieth-Century Demography. Comparative Studies in Society and History, 38(1), 26-66.

Hablicsek L. (1995). Az első és második demográfiai átmenet Magyarországon és Közép-Kelet-Európában. Budapest: KSH Népességtudományi Kutató Intézet. 
Haines, M. R. (1998). The Relationship Between Infant and Child Mortality and Fertility: Some Historical and Contemporary Evidence for the United States. In M. R. Montgomery and B. Cohen, (Eds.), From Death to Birth: Mortality Decline and Reproductive Change (pp. 227-253). Washington, D. C: National Academy Press.

Henry, L. (1961). Some data on natural fertility. Eugenics Quarterly, 8(2), 81-91.

Hirschman, C. (1994). Why Fertility Changes. Annual Review of Sociology, 20(1), 203-233. Hodgson, D. (1988). Orthodoxy and Revisionism in American Demography. Population and Development Review, 14(4), 541-569.

Hodgson, D. and Watkins, S. C. (2003). Feminists and Neo-Malthusians: Past and Present Alliances. Population and Development Review, 23(3), 469-523.

Hugo, G. (1998). Intergenerational Wealth Flows and the Elderly in Indonesia. In G. W. Jones, R. M. Douglas, J. C. Caldwell and R. M. Souza, (Eds.), The Continuing Demographic Transition (pp. 111-133). Oxford: Clarendon Press.

Johnson-Hanks, J. (2008). Demographic Transitions and Modernity. Annual Review of Anthropology, 37, 301-315.

Jones, H. (Ed.) (2009). OCR GCSE Geography: Specification B. Harlow: Pearson.

Jónás I., Kovács L. és Vízvári A. (2011). Földrajz: Kozmikus és természetföldrajzi környezetünk. Szeged: Mozaik.

Kaiser, J. (2001). Does Family Planning Bring Down Fertility? Science, 333(6042), 548-549.

Kaplan, H. (1994). Evolutionary and Wealth Flows Theories of Fertility: Empirical Tests and New Models. Population and Development Review, 20(4), 753-791.

Katus L. (1980). A demográfiai átmenet kérdései Magyarországon a 19. században. Történelmi Szemle, 23(2), 270-288.

Keyfitz, N. (1990). Alfred Sauvy. Population and Development Review, 16(4), 727-733.

Kirk, D. (1944). Population Changes and the Postwar World. American Sociological Review, 9(1), 28-35.

Kirk, D. (1996). Demographic Transition Theory. Population Studies, 50(3), 361-387.

Knodel, J. and van de Walle, E. (1979). Lessons from the Past: Policy Implications of Historical Fertility Studies. Population and Development Review, 5(2), 217-245.

Knowles, J. C., Akin, J. S. and Guilkey, D. K. (1994). The Impact of Population Policies: Comment. Population and Development Review, 20(3), 611-615.

Kovács K. (2011). Társadalmi egyenlötlenségek a mortalitásban Magyarországon (1971-2008) és az epidemiológiai átmenet elmélete. Budapest: KSH Népességtudományi Kutatóintézet.

Kovács Z. (2002). Népesség- és településföldrajz. Budapest: ELTE TTK.

Knöbl, W. (2003). Theories That Won't Pass Away: The Never-ending Story of Modernization Theory. In G. Delanty and E. F. Isin, (Eds.), Handbook of Historical Sociology (pp. 96-107). London: Sage.

Kreager, P. (2015). Population theory-A long view. Population Studies, 69(S1), S29-S37.

Lader, L. (1971). Breeding Ourselves to Death. New York: Ballantine Books.

Landry, A. (1934). La Révolution Démographique. Paris: Receuil Sirey.

Landry, A. (1987). Adolphe Landry on the Demographic Revolution. Population and Development Review, 13(4), 731-740. 
Lee, R. D. (1987). Population Dynamics of Humans and Other Animals. Demography, 24(4), 443-465.

Lee, J. and Wang, F. (1999). One-Quarter of Humanity. Malthusian Mythology and Chinese Realities, 1700-2000. Cambridge: Harvard University Press.

Lesthaeghe, R. (1980). On the Social Control of Human Reproduction. Population and Development Review, 6(4), 527-548.

Livi-Bacci, M. (1986). Social-Group Forerunners of Fertility Control in Europe. In A. J. Coale and S. C. Watkins, (Eds.), The Decline of Fertility in Europe: The Revised Proceedings of a Conference on the Princeton European Fertility Project (pp. 182-200). Princeton: Princeton University Press.

Livi-Bacci, M. (1999 [1992]). A világ népességének rövid története (fordította Soproni A.). Budapest: Osiris.

Mackenroth, G. (1953). Bevölkerungslehre. Theorie, Soziologie und Statistik der Bevölkerung. Berlin: Springer-Verlag.

Malthus, T. R. (1902 [1826]). Tanulmány a népesedés törvényéröl (fordította György E.). Budapest: Politzer Zsigmond és Fia.

Mason, K. O. (1997). Explaining Fertility Transitions. Demography, 34(4), 443-454.

Mass, B. (1974). An Historical Sketch of the American Population Control Movement. International Journal of Health Services, 4(4), 651-676.

Melegh A. (2000). Az angolszász globális népesedéspolitikai diskurzusok alakulása a 20. században: Lépések a pro- és antinatalista népesedéspolitikák összehasonlító vizsgálata irányában. Replika, 39, 157-175.

Melegh A. (2006). On the East-West Slope: Globalization, nationalism, racism and discourses on Central and Eastern Europe. Budapest-New York: Central European University Press.

Melegh A. (2014). Biopolitika, régiók és demográfia. In Őri P., (szerk.), Szám-(és betü) vetés: Tanulmányok Faragó Tamás tiszteletére (23-58. o.). Budapest: KSH Népességtudományi Kutatóintézet.

Miller, G. and Babiarz, K. S. (2016). Family Planning Program Effects: Evidence from Microdata. Population and Development Review, 42(1), 7-26.

Morgan, S. P. and Rybińska, A. (2019). Fertility. In D. L. Poston, Jr., (Ed.), Handbook of Population (pp. 319-342). Cham: Springer.

Notestein, F. W. (1945). Population - The long view. In T. W. Schultz, (Ed.), Food for the world (pp. 36-57). Chicago: University of Chicago Press.

Notestein, F. W. (1953). Economic problems of population change. In: Proceedings of the Eight International Conference of Agricultural Economists (pp. 13-31). London: Oxford University Press.

Őri P. (2018). A termékenységi átmenet mintái egy mikrorégióban (Zsámbék, Tök és Perbál) a 19. század végén, a 20. század első felében. Demográfia, 61(1), 53-90.

Petit, V. and Charbit, Y. (2012). The French School of Demography: Contextualizing Demographic Analysis. Population and Development Review 38(Supplement), 322-333.

Pokol B. (1987). A funkcionalista rendszerelmélet kibomlása: Talcott Parsons és Niklas Luhmann társadalomelméletének kategóriáiról. In Csepeli Gy., Papp Zs. és Pokol B., (szerk.), Modern polgári társadalomelméletek: Alfred Schütz, Jürgen Habermas, Talcott Parsons és Niklas Luhmann rendszere (153-324. o.). Budapest: Gondolat. 
Pritchett, L. H. (1994a). Desired Fertility and the Impact of Population Policies. Population and Development Review, 20(1), 1-55.

Pritchett, L. H: (1994b). The Impact of Population Policies: Reply. Population and Development Review, 20(3), 621-630.

Rao, M. (2004). From Population Control to Reproductive Health: Malthusian Arithmetic. New Delhi: Sage.

Rawls, A. W. (2018). The wartime narrative in US sociology, 1940-1947: stigmatizing qualitative sociology in the name of 'science'. European Journal of Social Theory, 21(4), 526-546.

Reed, J. (1984). The Birth Control Movement and American Society: From Private Vice to Public Virtue. Princeton: Princeton University Press.

Rees, P. (2009). Demography. In R. Kitchin and N. Thrift, (Eds.), International Encyclopedia of Human Geography (pp. 75-90). Amsterdam: Elsevier.

Reher, D. S. (1999). Back to the basics: mortality and fertility interactions during the demographic transition. Continuity and Change, 14(1), 9-31.

Reher, D. S. (2004). The demographic transition revisited as a global process. Population, Space and Place, 10(1), 19-41.

Reher, D. S. (2011). Economic and Social Implications of the Demographic Transition. Population and Development Review, 37(Supplement), 11-33.

Reher, D. S. (2019). The Aftermath of the Demographic Transition in the Developed World: Interpreting Enduring Disparities in Reproductive Behavior. Population and Development Review, 00(0): 1-29.

Robbins, P. (1998). Population and Pedagogy: The Geography Classroom after Malthus. Journal of Geography, 97(6), 241-252.

Robey, B., Rutstein, S. O. and Morris, L. (1993). The Fertility Decline in Developing Countries. Scientific American, 296(6), 60-67.

Ross, E. A. (1928). Standing Room Only? London: Chapman \& Hall.

Saito, O. (2015). Historical Demography. In J. D. Wright, (Ed.), International Encyclopedia of the Social \& Behavioral Sciences, vol. 11 (pp. 5-9). Amsterdam: Elsevier.

Santow, G. (1995). Coitus interruptus and the Control of Natural Fertility. Population Studies, 49(1), 19-43.

Sánchez-Barricarte, J. J. (2017). Mortality-fertility synergies during the demographic transition in the developed world. Population Studies, 71(2), 155-170.

Sharpless, J. (1995). World Population Growth, Family Planning, and American Foreign Policy. Journal of Policy History, 7(1), 72-102.

Singh, K. (1988). Development is the Best Contraceptive. Interdisciplinary Science Reviews, 13(4), 301-302.

Stix, R. K. and Notestein, F. W. (1934). Effectiveness of Birth Control: A Study of Contraceptive Practice in a Selected Group of New York Women. The Milbank Memorial Fund Quarterly, 12(1), 57-68.

Stycos, J. M. (1977). Desexing Birth Control. Family Planning Perspectives, 9(6), 286-292.

Szentgáli T. (1991). A demográfiai átmenet elmélete. Történeti Demográfiai Füzetek, 9 , 21-34. 
Szołtysek, M. (2007). Science without Laws? Model Building, Micro Histories and the Fate of the Theory of Fertility Decline. Historical Social Research / Historische Sozialforschung, 32(2), 10-41.

Szreter, S. (1993). The Idea of Demographic Transition and the Study of Fertility Change: A Critical Intellectual History. Population and Development Review, 19(4), 659-701.

Teitelbaum, M. S. (1984). The British Fertility Decline: Demographic Transition in the Crucible of the Industrial Revolution. Princeton: Princeton University Press.

Teitelbaum, M. S. and Winter, J. M. (1985). The Fear of Population Decline. Orlando: Academic Press.

Thompson, W. S. (1929). Population. American Journal of Sociology 34(6), 959-975.

Thornton, A. (2001). The Developmental Paradigm, Reading History Sideways, and Family Change. Demography, 38(4), 449-465.

Tomka B. (2009). Európa társadalomtörténete a 20. században. Budapest: Osiris.

Tsui, A. O. (2001). Population Policies, Family Planning Programs, and Fertility: The Record. Population and Development Review, 27(Supplement), 184-204.

Tsuya, N. O., Feng, W., Alter, G., Lee, J. Z., et al. (Eds.) (2010). Prudence and Pressure: Reproduction and Human Agency in Europe and Asia, 1700-1900. Cambridge: The MIT Press.

Valkovics E. (1982). A demográfiai átmenet elemzésének néhány gyakorlati nehézségéröl. Budapest: KSH Népességtudományi Kutató Intézet.

van Bavel, J. (2004). Deliberate Birth Spacing before the Fertility Transition in Europe: Evidence from Nineteenth-Century Belgium. Population Studies, 58(1), 95-107.

van de Kaa, D. J. (1996). Anchored Narratives: The Story and Findings of Half a Century of Research into the Determinants of Fertility. Population Studies, 50(3), 389-432.

van de Walle, E. (1992). Fertility Transition, Conscious Choice, and Numeracy. Demography, 29(4), 487-502.

van de Walle, F. (1986). Infant mortality and the European demographic transition. In A. J. Coale and S. C. Watkins, (Eds.), The Decline of Fertility in Europe: The Revised Proceedings of a Conference on the Princeton European Fertility Project (pp. 201-233). Princeton: Princeton University Press.

Vance (1952). Is Theory for Demographers? Social Forces, 31(1), 9-13.

Vasary, I. (1989). 'The sin of Transdanubia': the one-child system in rural Hungary. Continuity and Change, 4(3), 429-468.

Watkins, S. C. (1986). Conclusions. In A. J. Coale and S. C. Watkins, (Eds.), The Decline of Fertility in Europe: The Revised Proceedings of a Conference on the Princeton European Fertility Project (pp. 420-449). Princeton: Princeton University Press.

Wilson, C. (2003). Homeostasis. In P. Demeny and G. McNicoll, (Eds.), Encyclopedia of Population (pp. 493-496). New York: Macmillan Reference.

Wilson, C. and Airey, P. (1999). How can a homeostatic perspective enhance demographic transition theory? Population Studies, 53(2), 117-128. 


\section{A THEORY ABOVE ALL: CHANGE AND PERMANENCE IN THE SCIENTIFIC THOUGHT OF DEMOGRAPHIC TRANSITION}

\section{ABSTRACT}

The demographic transition theory is considered to be one of the best known generalisations in the history of social sciences. This paper discusses the circumstances of the emergence of transition theory through a critical analysis of Western discourses, and outlines the historical, cultural, and political context in which the theory has been raised. Through critical deconstruction, the analysis points out the teleological features of the model and its embeddedness in the modernization paradigm. Furthermore, a detailed literature review unfolds how traditional demographic thinking idealised the idea of demographic equilibria. In doing so, the paper demonstrates how the concept of natural fertility used as an epistemological basis in the European Fertility Project (EFP) strengthened the dichotomisation of demographic timeline, and how such a dualistic approach led to the establishment of a causal relationship between fertility and mortality. To conclude, the paper argues that demographic transition theory has been the culmination of a deep intellectual discourse interwoven with the Malthusian thought of homeostasis, and at its very beginning has been adapted to the needs of a globalised Western population policy, conserving these inherent traits in later decades. 